\title{
Gold in Bimetallic Molecular Clusters
}

\author{
THEIR SYNTHESIS, BONDING, CHEMICAL AND CATALYTIC REACTIVITIES
}

\author{
P. Braunstein and J. Rose \\ Laboratoire de Chimie de Coordination, Université Louis Pasteur, Strasbourg, France
}

\begin{abstract}
Gold-containing mixed-metal clusters and cluster compounds have been studied increasingly over the past few years. In this article the synthesis, structure and chemical reactivity of molecular cluster compounds in which gold is associated with one or more transition metals are reviewed. The bimetallic associations encountered at the molecular level are also examined in view of their importance in homogeneous, supported, and beterogeneous catalysis. The improved catalytic properties of gold-containing bimetallic over monometallic chusters have been described elsewhere in this issue by J. Schwank.
\end{abstract}

The area of transition metal cluster compounds has attracted an expanding interest over the recent years. This is particularly notable in the field of mixed-metal cluster compounds, i.e. of complexes containing at least three metal atoms and characterized by heteronuclear metal-metal bonds. Recent reviews have illustrated the related advances made in academic and industrial research laboratories (1-6). A particular class of mixed-metal cluster compounds has enjoyed exponentially increasing interest over the last three years and consists of those of gold-transition metals. It is the purpose of the present article to review major developments in the area of cluster chemistry and relate them to other disciplines, by presenting selected rather than comprehensive examples.

Our aim will be to illustrate the synthetic potential of coordination and organometallic chemistry, which enables the construction of unique molecular architectures. Not only does it provide access to a wide collection of structural types, but it also allows the combination and interaction in the same molecule of different metals, creating therefore new metal-metal bonds and/or bonding modes. Unique reactivity patterns and dynamic behaviour in solution have been reported which can be ascribed to the presence of one or more gold units in a cluster compound. A wide variety of sometimes predictable and stepwise syntheses of gold-containing polymetallic cluster compounds is now well-known to organometallic chemists and it is interesting to compare this situation with that sometimes encountered in solid state chemistry. Thus elemental metallic clusters of, for example, gold and ruthenium, or gold and osmium cannot be effectively studied in the solid state because the corresponding binary combinations are immiscible. In contrast, many examples are known of molecularcluster compounds in which atoms of these metals are clustered together through direct metal-metal bonds. The number of known clusters of this type containing three or four different metals is rapidly growing. Conceptually filling the gap between the extremes, highly dispersed bimetallic particles may present heterometallic metal-metal interactions unknown in the bulk state. This has been demonstrated, for example, in the copper-ruthenium $\operatorname{system}(7,8)$. These aspects are of obvious relevance to the numerous catalytic properties of these materials.

\section{Methods of Synthesis}

We would like to concentrate in this paper mainly on a class of cluster compounds which has grown very rapidly over the past few years, namely that containing one or more peripheral $\mathrm{L} \rightarrow \mathrm{Au}$ fragments, L being a two-electron donor (for example, phosphine). The concentration of synthetic effort on this type of cluster results largely from the recognized isolobal analogy between $\mathrm{L} \rightarrow$ Au and $\mathrm{H}(9,10)$ (see Figure 1), suggesting that hydrido clusters could be precursors of structurally related mixed-metal clusters containing one or more $\mathrm{L} \rightarrow$ Au fragments. As shown below, knowledge of the molecular structure of the latter often enables a reasonable hy pothesis to be made about the structure of the hydrido precursor

Fig. 1 A comparison of the frontier molecular orbitals of $\mathrm{Au}\left(\mathrm{PH}_{3}\right)$ and $\mathrm{H}$. Adapted from (10)
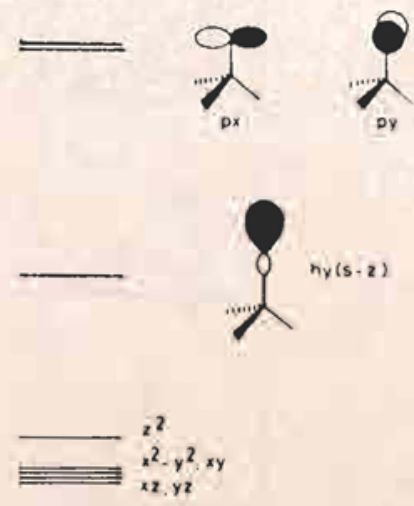

$z^{2}-y^{2}-x y$
$x^{2}-y^{2}$
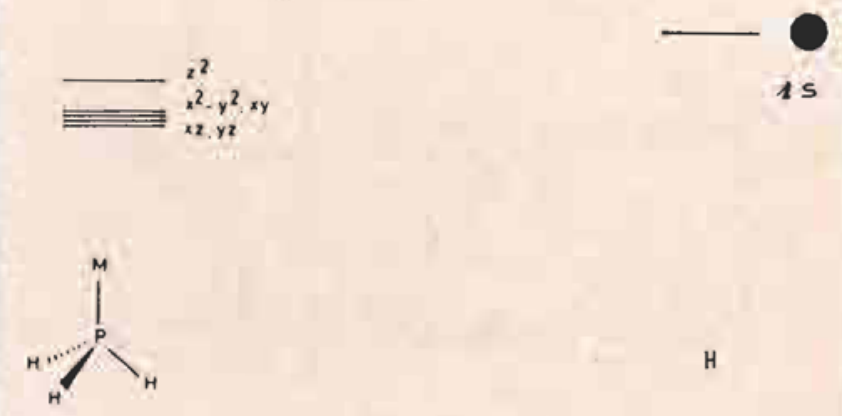

H 
Table I

Clusters Containing one AuPR Fragment

\begin{tabular}{|c|c|c|c|c|c|c|c|c|}
\hline Entry & Cluster & $\begin{array}{l}\text { Metallic core } \\
\text { structure }^{\star}\end{array}$ & $\mathrm{CVE}^{\star \star}$ & $\begin{array}{l}\text { Co-ordination } \\
\text { modes of AuPR } \\
\text { (bridged atoms) }\end{array}$ & $\begin{array}{c}\text { Synthetic } \\
\text { route }\end{array}$ & $\begin{array}{c}\text { Au-M distances }(\AA) \\
\text { (esd) }\end{array}$ & Comments & Ref. \\
\hline 1 & $\mathrm{Fe}_{3}\left(\mu-\mathrm{HC}=\mathrm{NBu}^{\prime}\right)(\mathrm{CO})_{9}\left(\mu-\mathrm{AuPPh}_{3}\right)$ & & 60 & $\mu_{2}-\left(\mathrm{Fe}_{2}\right)$ & 2.1 & $\begin{array}{rr}\text { Au-Fe } & 2.671(3) \\
& 2.679(3) \\
\text { and } & 2.659(2) \\
& 2.717(3)\end{array}$ & $\begin{array}{l}\text { Two independent } \\
\text { molecules in the } \\
\text { unit cell }\end{array}$ & 15 \\
\hline 2 & $\mathrm{Ru}_{3}(\mu-\mathrm{Cl})(\mathrm{CO})_{10}\left(\mu-\mathrm{AuPPh}_{3}\right)$ & & 60 & $\mu_{z}-\left(\mathrm{Ru}_{2}\right)$ & 2.2 & $\begin{array}{r}\text { Au-Ru } 2.7523(6) \\
2.7549(6)\end{array}$ & & 16 \\
\hline 3 & $\mathrm{Ru}_{3}(\mu-\mathrm{H})(\mu-\mathrm{PPh})(\mathrm{CO})_{9}\left(\mu-\mathrm{AuPPhMe}_{2}\right)$ & & 60 & $\mu_{2}-\left(\mathrm{Ru}_{2}\right)$ & 4 & $\begin{array}{r}\text { Au-Ru } 2.749(4) \\
2.763(4)\end{array}$ & & 17 \\
\hline 4 & $\mathrm{Ru}_{3}(\mu-\mathrm{H})_{2}\left(\mu_{3}-\mathrm{COMe}\right)(\mathrm{CO})_{9}\left(\mu-\mathrm{AuPPh}_{3}\right)$ & & 60 & $\mu_{2}=\left(R u_{2}\right)$ & 1 & $\begin{array}{r}\text { Au-Ru } 2.727(1) \\
2.763(1)\end{array}$ & & $\begin{array}{l}18, \\
19\end{array}$ \\
\hline 5 & $\mathrm{Ru}_{3}(\mu-\mathrm{COMe})(\mathrm{CO})_{10}\left(\mu-\mathrm{AuPPh}_{3}\right)$ & & 60 & $\mu_{2}-\left(R u_{2}\right)$ & 1 & $\begin{array}{r}\text { Au-Ru } 2.760(2) \\
2.762(2)\end{array}$ & & 20 \\
\hline 6 & $\mathrm{Ru}_{3}\left(\mathrm{C}_{2} \mathrm{Bu}^{\prime}\right)(\mathrm{CO})_{9}\left(\mu-\mathrm{AuPPh}_{3}\right)$ & & 60 & $\mu_{2}-\left(R u_{2}\right)$ & 2.1 & $\begin{array}{r}A u-R u 2.757(1) \\
2.763(1)\end{array}$ & & 21 \\
\hline 7 & $\begin{array}{l}\mathrm{Os}_{3}(\mu-\mathrm{X})(\mathrm{CO})_{10}\left(\mu-\mathrm{AuPPh}_{3}\right) \\
\mathrm{X}=\mathrm{Cl}, \mathrm{Br}\end{array}$ & & 60 & $\mu_{2}-\left(\mathrm{Os}_{2}\right)$ & 2.2 & $\begin{array}{c}\text { Au-Os } 2.77 \mathrm{Cl} \\
2.75 \\
2.73 \mathrm{Br} \\
2.76\end{array}$ & & 22 \\
\hline 8 & $\mathrm{OS}_{3}(\mu-\mathrm{H})(\mathrm{CO})_{10}\left(\mu-\mathrm{AuPPh}_{3}\right)$ & & 58 & $\mu_{z}-\left(\mathrm{Os}_{2}\right)$ & 3.1 & $\begin{array}{r}\text { Au-Os } 2,772(2) \\
2.738(1)\end{array}$ & & 23 \\
\hline 9 & $\mathrm{Os}_{3}(\mu-\mathrm{SCN})(\mathrm{CO})_{10}\left(\mu-\mathrm{AuPPh}_{3}\right)$ & & 60 & $\mu_{2}-\left(\mathrm{Os}_{2}\right)$ & 2.2 & $\begin{array}{r}\text { Au-Os } 2.768(1) \\
2.755(1)\end{array}$ & & 23 \\
\hline 10 & {$\left[\mathrm{Pt}_{3}(\mathrm{CO})_{3}\left(\mathrm{PCy}_{3}\right)_{3}\left(\mu_{3}-\mathrm{AuPCy}_{3}\right)\right]^{\oplus}$} & & 54 & $\mu_{3}-\left(\mathrm{Pt}_{3}\right)$ & 3.3 & $\begin{array}{r}\text { Au-Pt } 2.768(5) \\
2.757(5) \\
2.750(5)\end{array}$ & & 24 \\
\hline 11 & $\mathrm{FeCoRu}\left(\mu_{3}-\mathrm{PMe}\right)(\mathrm{CO})_{9}\left(\mu-\mathrm{AuPPh}_{3}\right)$ & & 60 & $\mu_{2}-(\mathrm{FeRu})$ & 2.1 & $\begin{array}{l}\text { Au-Fe } 2.677(2) \\
\text { Au-Ru } 2.729(2)\end{array}$ & $\begin{array}{l}\text { Cluster with foùr } \\
\text { different metals }\end{array}$ & 25 \\
\hline
\end{tabular}




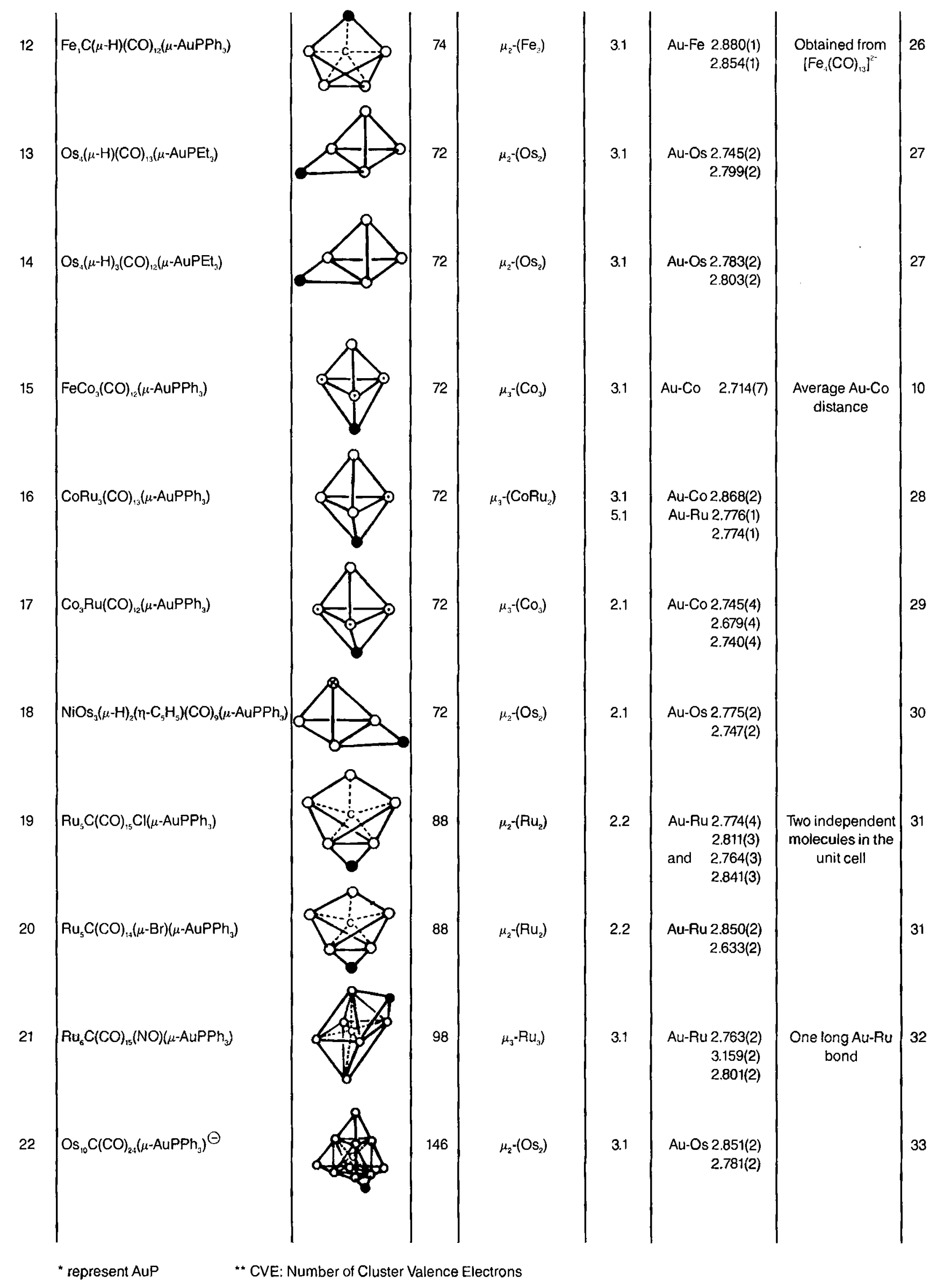


Table II

Clusters Containing two AuPR, Fragments

\begin{tabular}{|c|c|c|c|c|c|c|c|c|}
\hline Entry & Cluster & $\begin{array}{l}\text { Metallic core } \\
\text { structure }\end{array}$ & CVE ${ }^{\star \star}$ & $\begin{array}{l}\text { Co-ordination } \\
\text { modes of AuPR } \\
\text { (bridged atoms) }\end{array}$ & $\begin{array}{l}\text { Synthetic } \\
\text { route }\end{array}$ & $\begin{array}{c}\text { Au-M distances }(\AA) \\
\text { (esd) }\end{array}$ & Comments & Ref. \\
\hline 23 & $\mathrm{Fe}(\mathrm{CO})_{1}\left(\mathrm{AuPPh}_{3}\right)_{2}$ & & 42 & $\begin{array}{l}\mu_{2}-(\mathrm{FeAu}) \\
\mu_{2}-(\mathrm{FeAu})\end{array}$ & - & Au-Au $\quad 2.977(1)$ & & 34 \\
\hline 24 & $\left.\mathrm{Os}(\mathrm{CO})_{4}(\mathrm{AuPPh})_{3}\right)_{2}$ & & 42 & $\begin{array}{l}\mu_{2}-(\text { OsAu }) \\
\mu_{2}-(\text { OsAu })\end{array}$ & 2.1 & $\begin{array}{lr}\mathrm{Au}-\mathrm{Au} & 2.929(1) \\
\mathrm{Au}(1)-\mathrm{Os} & 2.667(1) \\
\mathrm{Au}(2)-O s & 2.646(1)\end{array}$ & & 35 \\
\hline 25 & $\left.\mathrm{Pt}\left(\mathrm{PEt}_{\mathrm{j}}\right)_{2} \mathrm{Cl}(\mathrm{AuPPh})_{3}\right)_{2}^{\oplus}$ & & 40 & $\begin{array}{l}\mu_{2}-(\mathrm{PtAu}) \\
\mu_{2}-(\mathrm{PtAu})\end{array}$ & 3.2 & $\begin{array}{ll}\mathrm{Au}-\mathrm{Au} & 2.737(3) \\
\mathrm{Au}(1)-\mathrm{Pt} & 2.600(3) \\
\mathrm{Au}(2)-\mathrm{Pt} & 2.601(4)\end{array}$ & & 36 \\
\hline 26 & {$\left[\mathrm{Pt}_{2}(\mathrm{CN}-\mathrm{xylyl})_{4}\left(\mathrm{PPh}_{3}\right)_{2}\left(\mu_{3}-\mathrm{AuPPh}_{3}\right)_{2}\right]^{2+}$} & & 56 & $\begin{array}{l}\mu_{3}-\left(\mathrm{Pt}_{2} \mathrm{Au}\right) \\
\mu_{3}-\left(\mathrm{Pt}_{2} \mathrm{Au}\right)\end{array}$ & 4 & $\begin{array}{ll}\mathrm{Au}-\mathrm{Au} & 2.590(2) \\
\mathrm{Au}(1)-\mathrm{Pt} & 2.717(2) \\
& 2.711(2) \\
\mathrm{Au}(2)-\mathrm{Pt} & 2.922(2) \\
& 3.026(2)\end{array}$ & & 37 \\
\hline 27 & $F e_{3}\left(\mu_{3}-\mathrm{S}\right)(\mathrm{CO})_{9}\left(\mu-\mathrm{AuPPh}_{\mathrm{J}}\right)_{2}$ & & 72 & $\begin{array}{l}\mu_{3}-\left(\mathrm{Fe}_{2} \mathrm{Au}\right) \\
\mu_{4}-\left(\mathrm{Fe}_{3} \mathrm{Au}\right)\end{array}$ & 2.1 & \begin{tabular}{|lr} 
Au-Au & $3.020(1)$ \\
Au(1)-Fe & $2.722(3)$ \\
& $2.698(4)$ \\
$2.746(3)$ \\
Au(2)-Fe $2.671(3)$ \\
$2.750(4)$
\end{tabular} & & 38 \\
\hline 28 & $R u_{3}\left(\mu_{3}-S\right)(C O)_{8}\left(P P h_{3}\right)\left(\mu-A u P P h_{3}\right)_{2}$ & & 72 & $\begin{array}{l}\mu_{3}-\left(R u_{2} A u\right) \\
\mu_{4}-\left(R u_{3} A u\right)\end{array}$ & 1 & $\begin{array}{lr}\text { Au-Au } & 2.915(2) \\
\text { Au(1)-Ru } 2.861(2) \\
2.784(2) \\
2.897(2) \\
\text { Au(2)-Ru } 2.807(2) \\
2796(2)\end{array}$ & & 39 \\
\hline 29 & $R u_{3}(\mu-\mathrm{H})(\mu-\mathrm{COMe})(\mathrm{CO})_{9}\left(\mu-\mathrm{AuPPh}_{3}\right)_{2}$ & & 72 & $\begin{array}{l}\mu_{3}-\left(\mathrm{Ru} u_{2} \mathrm{Au}\right) \\
\mu_{3}-\left(\mathrm{R} \mathrm{u}_{2} \mathrm{Au}\right)\end{array}$ & 1 & $\begin{array}{lr}\text { Au-Au } & 3.176(1) \\
\mathrm{Au}(1)-\mathrm{Ru} & 2.735(1) \\
2.749(1) \\
\mathrm{Au}(2)-\mathrm{Ru} 2.796(1) \\
2.702(1)\end{array}$ & & 39 \\
\hline 30 & $\mathrm{Fe}_{4} \mathrm{C}(\mathrm{CO})_{12}\left(\mu-\mathrm{AuPEt}_{3}\right)_{2}$ & & 86 & $\begin{array}{l}\mu_{4}-\left(\mathrm{Fe} e_{3} \mathrm{Au}\right) \\
\mu_{4}-\left(\mathrm{Fe}_{3} \mathrm{Au}\right)\end{array}$ & 3.1 & $\begin{array}{lr}\mathrm{Au}-\mathrm{Au} & 3.017(1) \\
\mathrm{Au}(1)-\mathrm{Fe} & 2.770(1) \\
& 2.999(2) \\
& 2.982(2)\end{array}$ & & 26 \\
\hline
\end{tabular}




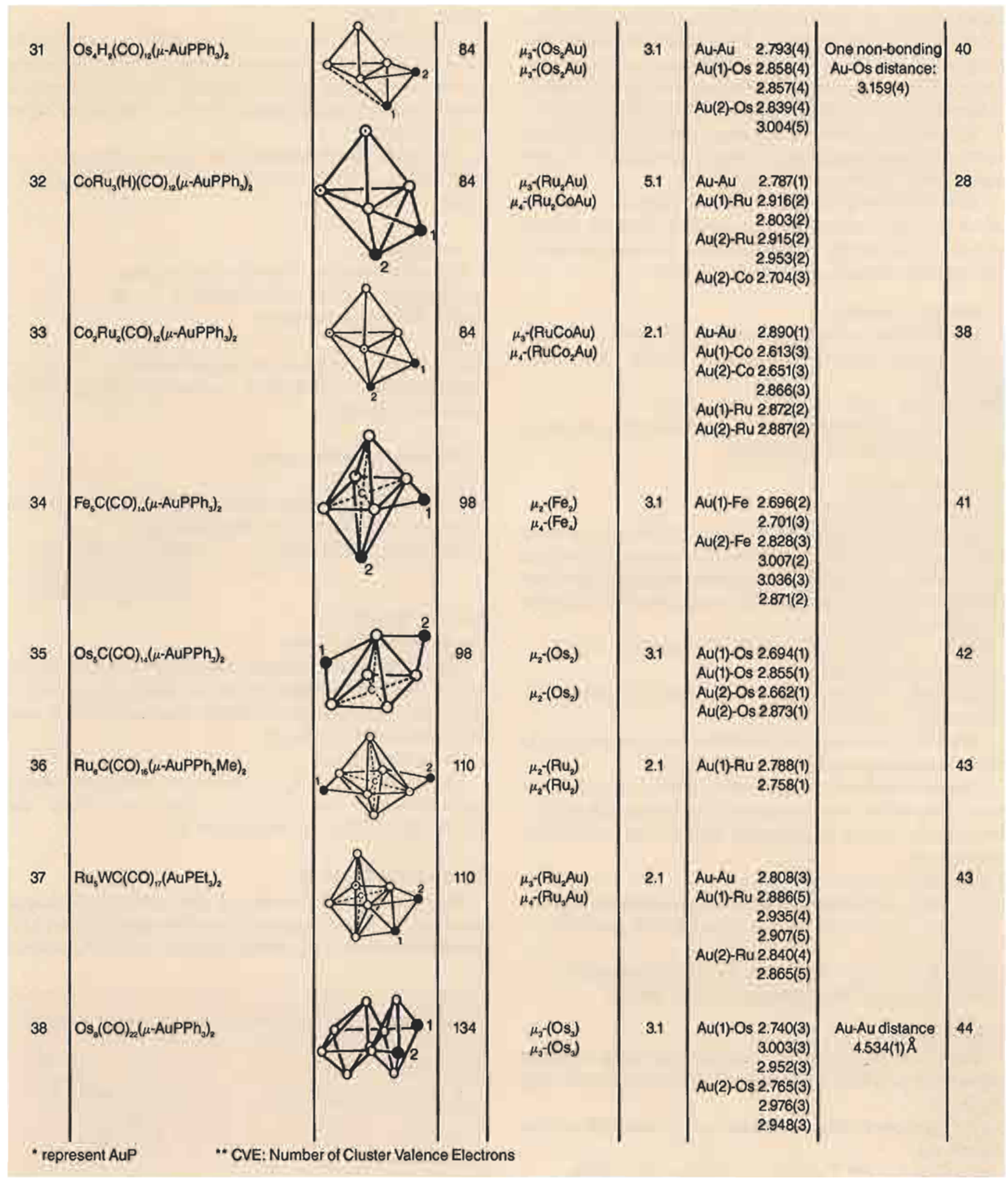


for which the position of the hydride ligand is more difficult to ascertain by X-ray diffraction (11). Thus, we shall not discuss chain compounds of the type M-Au-M where $\mathrm{M}$ is a mononuclear (12a, 13a) or a cluster fragment (14), nor shall we refer to gold-containing clusters for which the crystal structures have not been reported.

The synthetic methods used to prepare gold-containing mixedmetal cluster compounds can be classified according to the gold complex used and the reaction conditions.

Tables I-IV list the $\mathrm{L} \rightarrow \mathrm{Au}$-containing mixed-metal clusters which have been structurally characterized. They are ordered according to the number of gold atoms and the cluster nuclearity. The synthetic methods used are also indicated.

\section{From $\mathrm{R}_{3} \mathrm{P} \rightarrow \mathrm{Au}-\mathrm{CH}_{3}$}

This precursor can be reacted with hydrido homo- or heterometal clusters to give a condensation reaction with alkane elimination:

$\mathrm{R}_{3} \mathrm{P} \rightarrow \mathrm{Au}-\mathrm{CH}_{4}+\mathrm{M}_{\mathrm{x}} \mathrm{L}_{5} \longrightarrow \mathrm{R}_{\mathrm{s}} \mathrm{P}_{\rightarrow} \mathrm{M}_{\mathrm{s}}+\mathrm{CH}_{i}$

Clusters prepared according to this method are given in entries $(4,5,28,29,41$ and 42$)$ of Tables I-III.

\section{From $\mathbf{R}_{3} \mathbf{P} \rightarrow \mathrm{Au}-\mathrm{Cl}$}

\subsection{Substitution Reaction}

Following the pioneering work of Nyholm et al. using $\mathrm{Ph}_{3} \mathrm{P} \rightarrow \mathrm{AuCl}$ to prepare heterobimetallic complexes by reaction with carbonylmetallates (51), most cluster compounds have been obtained by reaction of an anionic mononuclear or cluster complex with $\mathrm{R}_{3} \mathrm{P} \rightarrow \mathrm{Au}-\mathrm{Cl}$, e.g.

$\mathrm{V}(\mathrm{CO})^{3}{ }_{3}+3 \mathrm{Ph}_{3} \mathrm{P} \rightarrow \mathrm{AuCl} \longrightarrow \mathrm{V}(\mathrm{CO})_{3}\left(\mathrm{AuPPh}_{3}\right)_{3}+3 \mathrm{Cl}^{-}$

(see entry 39, Table III)

$\mathrm{Co}_{3} \mathrm{Ru}(\mathrm{CO})_{12}{ }^{-}+\mathrm{Ph}_{3} \mathrm{P} \rightarrow \mathrm{AuCl} \longrightarrow \mathrm{Co}_{3} \mathrm{Ru}(\mathrm{CO})_{12} \mathrm{AuPPh}_{3}+\mathrm{Cl}^{-}$

(See entry 17, Table I)

Hydrido clusters in the presence of base react in a way similar to the corresponding anions (entry 31 , Table II).

The nature of the cation associated with the metal carbonylate has a strong influence on its reactivity. It is sometimes necessary to facilitate the reaction by generating the $\mathrm{R}_{5} \mathrm{P} \rightarrow \mathrm{Au}^{+}$cation (see equation (3)).

\subsection{Oxidative Addition}

$\mathrm{R}_{\mathrm{s}} \mathrm{P} \rightarrow \mathrm{Au}-\mathrm{Cl}$ can oxidatively add on to neutral clusters, e.g.: $\mathrm{Os}_{3}(\mathrm{CO})_{12}+\mathrm{Ph}_{3} \mathrm{P} \rightarrow \mathrm{Au}-\mathrm{Cl} \longrightarrow \mathrm{Os}_{3}(\mu-\mathrm{Cl})(\mathrm{CO})_{11}\left(\mu-\mathrm{AuPPh}_{3}\right)$ (Entry 7, Table I)

$\mathrm{Ru}_{5} \mathrm{C}(\mathrm{CO})_{13}+\mathrm{Ph}_{3} \mathrm{P} \rightarrow \mathrm{AuCl} \longrightarrow \mathrm{Ru}_{3} \mathrm{C}(\mathrm{CO})_{13} \mathrm{Cl}\left(\mu-\mathrm{AuPPh}_{3}\right)$

(Entry 19, Table I) (See also entries 2, 9, 20, Table I).

\section{From $\left[\mathrm{Ph}_{\mathbf{s}} \mathbf{P} \rightarrow \mathrm{Au}\right]^{+}$}

This cation can be either generated in situ, using a chloride abstractor, e.g. TIPF, or prepared and stabilized separately, e.g. $\mathrm{AgCF}, \mathrm{SO}_{3}$.

3.1 As mentioned above, this cation easily reacts with anionic clusters, e.g.:

$$
\mathrm{FeCO}_{3}(\mathrm{CO})_{12}{ }^{-}+\left[\mathrm{Ph}_{3} \mathrm{P} \rightarrow \mathrm{Au}\right]^{+} \longrightarrow \mathrm{FeCo}_{3}(\mathrm{CO})_{12} \mathrm{AuPPh}_{3}
$$

(Entry 15, Table I)

(See also entries 8, 13, 14, 21, 22 in Table I; 30, 34, 35, 38 in Table II). $3.2\left[\mathrm{Ph}_{3} \mathrm{P} \rightarrow \mathrm{Au}\right]^{+}$has also been found to have a very interesting reactivity versus hydrido metal complexes. The first Au-Pt mixedmetal cluster (36) was obtained by this procedure (Figure 2) (See entries 25,40 ).

3.3 This gold cation reacts easily with neutral clusters e.g.:

$\mathrm{Pt}_{3}(\mathrm{CO})_{5}(\mathrm{PCy})_{3}+[\mathrm{PCy} \rightarrow \mathrm{Au}]^{+} \longrightarrow\left[\mathrm{Pt}_{3} \mathrm{Au}(\mathrm{CO})_{3}\left(\mathrm{PCy}_{3}\right)_{4}\right]^{+}$ (Entry 10, Table I).

\section{From $\left[\mathrm{AuL}_{2}\right]^{+}$}

Phosphine transfer is observed in the reaction:

$\left[\mathrm{Ru}_{3} \mathrm{H}(\mathrm{CO})_{9}\left(\mu_{3}-\mathrm{PPh}\right)\right]^{-}+\left[\mathrm{Au}\left(\mathrm{PPhMe}_{2}\right)_{2}\right]^{+} \longrightarrow$

$\mathrm{Ru}_{3} \mathrm{H}\left(\mu_{3}-\mathrm{PPh}\right)(\mathrm{CO})_{9} \mathrm{AuPPhMe}_{2}$

(Entry 3, Table I)

and isonitrile for phosphine exchange occurs in:

$\mathrm{Pt}\left(\mathrm{C}_{2} \mathrm{H}_{1}\right)\left(\mathrm{PPh}_{3}\right)_{2}+\left[\mathrm{Au}(\mathrm{CNR})_{2}\right]^{+} \longrightarrow\left[\mathrm{Pt}_{2} \mathrm{Au}_{2}\left(\mathrm{PPh}_{3}\right)_{4}(\mathrm{CNR})_{1}\right]^{2}$

(Entry 26, Table II)

\section{Polynuclear Gold Precursors}

5.1 From $\left[\left(R_{i} P A u\right), O\right]^{+}$

This oxonium reagent has been successfully used for the synthesis of clusters containing $\mathrm{R}_{i} \mathrm{P} \rightarrow \mathrm{Au}$ fragments, e.g.:

$$
\begin{aligned}
{\left[\mathrm{H}_{3} \mathrm{Ru}_{4}(\mathrm{CO})_{12}\right]^{-}+\left(\left(\mathrm{Ph}_{3} \mathrm{PAu}\right)_{3} \mathrm{O}\right\}^{*} \longrightarrow } & \mathrm{H}_{3} \mathrm{Ru}_{3}(\mathrm{CO})_{12} \mathrm{AuPPh}_{3}+ \\
& \mathrm{H}_{3} \mathrm{Ru}_{4}(\mathrm{CO})_{12}\left(\mathrm{AuPPh}_{3}\right)_{2}+ \\
& \mathrm{HRu}_{4}(\mathrm{CO})_{12}\left(\mathrm{AuPPh}_{3}\right)_{3}
\end{aligned}
$$

(Entry 42, Table III)

(See also entries 16, 32, 43).

This cation has the advantage of being able to replace one $\mathrm{CO}$ by two $\mathrm{Ph}, \mathrm{P} \rightarrow \mathrm{Au}$ groups, as well as acting as a source of $\mathrm{Ph}_{3} \mathrm{P} \rightarrow \mathrm{Au}^{+}$. It is therefore of higher synthetic potential than $\mathrm{Ph}_{3} \mathrm{P} \rightarrow \mathrm{AuCl}$ or $\mathrm{Ph}_{3} \mathrm{P} \rightarrow \mathrm{AuCH}_{3}$.

\subsection{From Gold Clusters}

The cationic $\left[\mathrm{Au}_{s}\left(\mathrm{PPh}_{3}\right)\right]^{2+}$ cluster has been reacted with 2 equivalents of the $\mathrm{Co}(\mathrm{CO})_{1}$ anion to afford the $\mathrm{Au}_{6}\left(\mathrm{PPh}_{3}\right)_{4}\left[\mathrm{Co}(\mathrm{CO})_{4}\right]_{2}$ cluster (See entry 46)

\section{Structure and Bonding}

The metallic core structures of the mixed metal clusters containing the $\mathrm{L} \rightarrow \mathrm{Au}$ fragment(s) are illustrated in Tables I-IV. They fall into various categories according to the bonding mode of

Fig. 2 Synthesis of the first platinum-gold cluster complex. After (36)

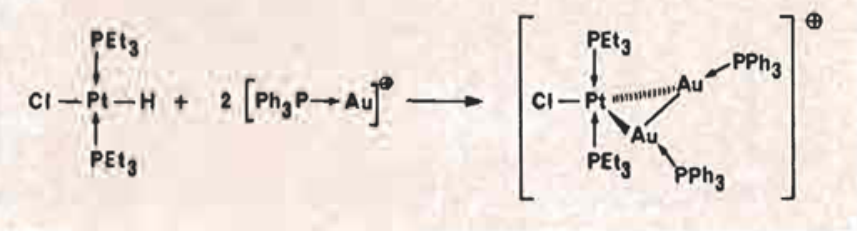


Table III

Clusters Containing three AuPR, Fragments

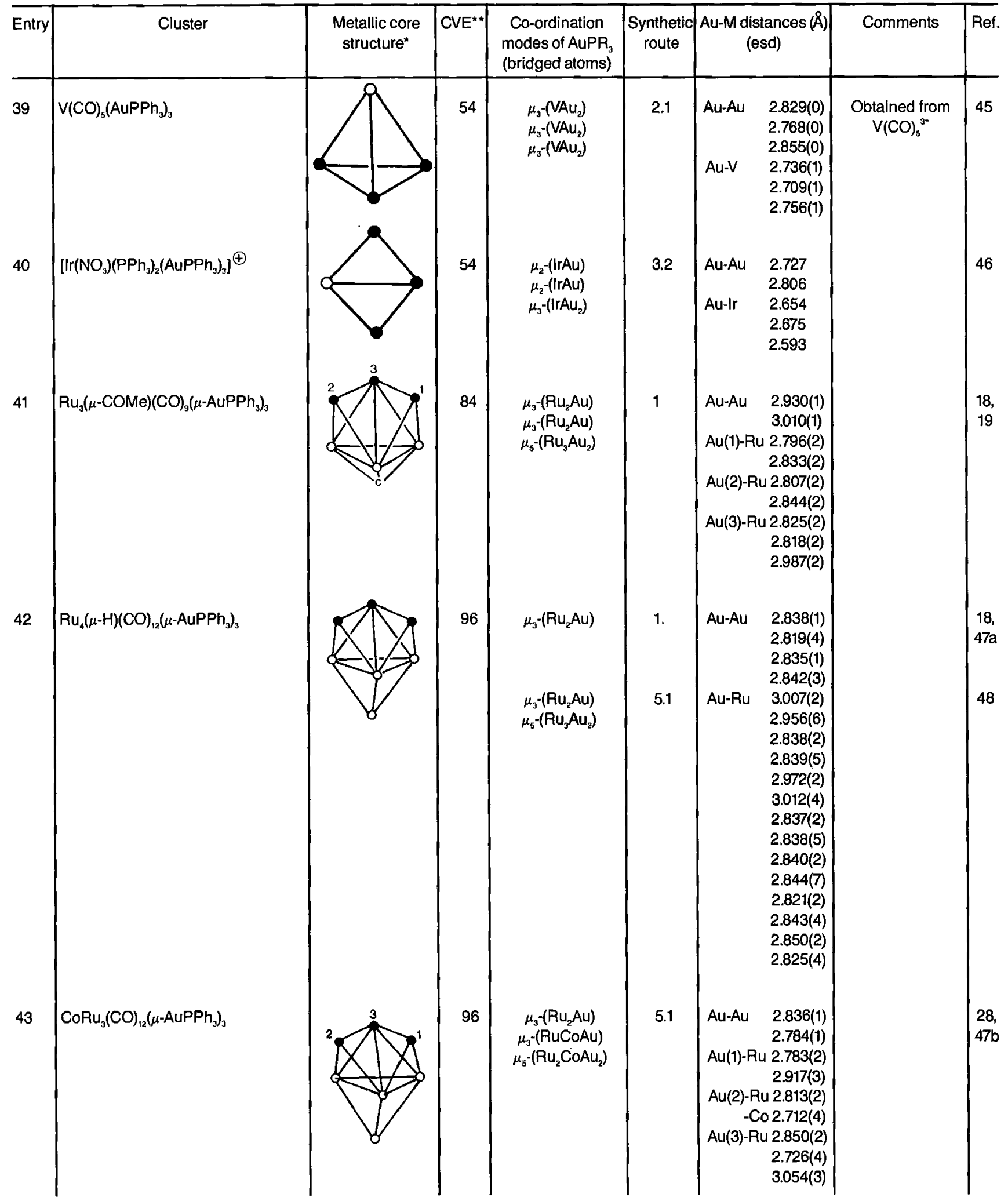

- represent AuP

** CVE: Number of Cluster Valence Electrons 
Table IV

Other Clusters Containing $\mathrm{AuPR}_{3}$ or $\mathrm{Au}_{2}$ PP Units

\begin{tabular}{|c|c|c|c|c|c|c|c|}
\hline Entry & Cluster & $\begin{array}{l}\text { Metallic core } \\
\text { structure }\end{array}$ & $\begin{array}{l}\text { Co-ordination } \\
\text { modes of AuPR } \\
\text { (bridged atoms) }\end{array}$ & $\begin{array}{l}\text { Synthetic } \\
\text { route }\end{array}$ & $\begin{array}{c}\text { Au-M distances }(\AA) \\
(\text { esd })\end{array}$ & Comments & Ref. \\
\hline 44 & {$\left[\mathrm{Fe}(\mathrm{CO})_{4}\left(\mathrm{Au}_{2} \mathrm{dppm}\right)\right]_{2}$} & & $\begin{array}{l}\mu_{3}-\left(\mathrm{FeAu}_{2}\right) \\
\mu_{3}-\left(\mathrm{FeAu}_{2}\right) \\
\mu_{4}-\left(\mathrm{FeAu}_{3}\right) \\
\mu_{4}-\left(\mathrm{FeAu}_{3}\right)\end{array}$ & 2.1 & 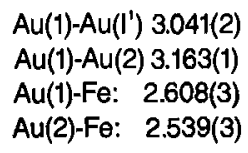 & $\begin{array}{l}\text { Incomplete X-ray } \\
\text { data }\end{array}$ & 49 \\
\hline 45 & {$\left[\mathrm{Fe}(\mathrm{CO})_{4}\left(\mathrm{Au} \mathrm{u}_{2} \mathrm{dpp} \theta\right)\right]_{2}$} & & $\begin{array}{l}\mu_{2}-(\mathrm{FeAu}) \\
\mu_{2}-(\mathrm{FeAu}) \\
\mu_{2}-(\mathrm{FeAu}) \\
\mu_{2}-(\mathrm{FeAu})\end{array}$ & 2.1 & $\begin{array}{ll}\mathrm{Au}(1)-\mathrm{Au}(2) & 2.977(1) \\
\mathrm{Au}(1)-\mathrm{Fe}: & 2.524(2) \\
\mathrm{Au}(2)-\mathrm{Fe}: & 2.535(2)\end{array}$ & $\begin{array}{l}\text { Incomplete X-ray } \\
\text { data }\end{array}$ & 49 \\
\hline 46 & $\left.\left.\mathrm{Au}_{2}(\mathrm{AuPPh})_{3}\right)_{4} \mathrm{Co}(\mathrm{CO})_{4}\right]_{2}$ & C & $\begin{array}{l}\mu_{3}-\left(A u_{2} A u^{x}\right) \\
\mu_{3}-\left(A u_{2} A u^{x}\right) \\
\mu_{5}-\left(A u_{3} A u_{2}^{x}\right) \\
\mu_{5}-\left(A u_{3} A u_{2}{ }^{x}\right)\end{array}$ & 5.2 & $\begin{array}{lr}\mathrm{Au}(1)-\mathrm{Au}\left(1^{\prime}\right) & 2.66 \\
\mathrm{Au}(2)-\mathrm{Au}(3) & 2.62 \\
\mathrm{Au}-\mathrm{Co} \quad 2.46\end{array}$ & $\begin{array}{c}\text { "Planar } \mathrm{Au}_{4} \mathrm{P}_{4} \\
\text { Surface" } \\
\text { Incomplete X-ray } \\
\text { data }\end{array}$ & 50 \\
\hline
\end{tabular}

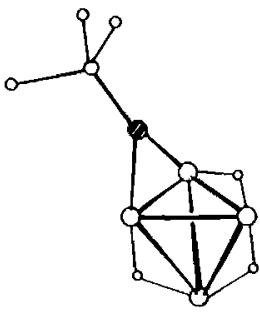

(a)

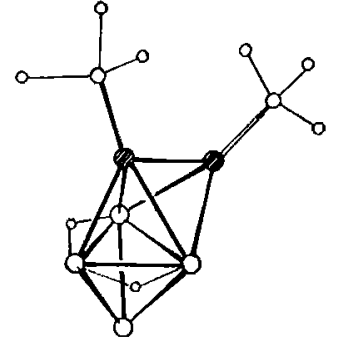

(b)

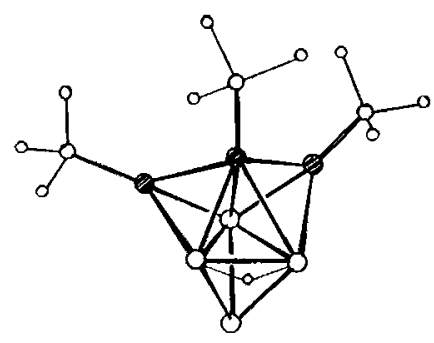

(c)

Fig. 3 Gold-ruthenium clusters with $A u R u_{4}, A u_{2} R u_{4}$ and $A u_{3} R u_{4}$ cores in

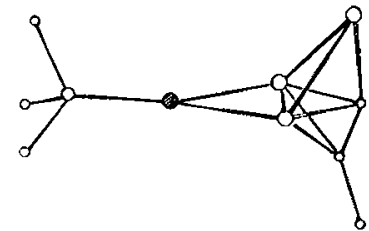

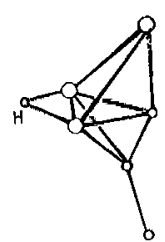

(b)

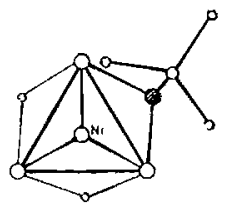

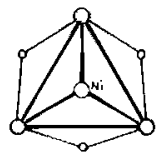

(d)

Fig. 4 Examples of $\mathrm{Ph}, \mathrm{P} \rightarrow \mathrm{Au}$ fragments in (a) and (c) occupying the position of the bridging hydride of the corresponding cluster (b) and (d), respectively.

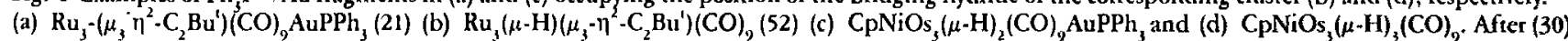


this fragment(s). In most examples the $\mathrm{L} \rightarrow A u$ groups are $\underline{\mu}_{2}$-bridging an edge or $\mu_{3}$-capping a face but $\mu_{4}$ and $\mu_{3}$ situations are also encountered in higher nuclearity clusters.

The isolobal analogy between $\mathrm{L} \rightarrow \mathrm{Au}$ and $\mathrm{H}$ has been in evidence $(9,10)$ and found to be very useful in predicting the synthesis and structure of many clusters containing the $\mathrm{L} \rightarrow \mathrm{Au}$ unit(s). This is particularly helpful for clusters containing one $\mathrm{L} \rightarrow$ Au fragment since it generally occupies the edge-bridging or face-capping position of $\mathrm{H}$ in the corresponding hydrido cluster. This is nicely verified in the cases where the hydride ligand has been located in the molecular structure of the cluster, as in, for example, $\mathrm{Ru}_{3}(\mu-\mathrm{H})\left(\mu_{3}-\eta^{2}-\mathrm{C}_{2} \mathrm{Bu}^{\prime}\right)(\mathrm{CO})_{2}(52)$ and $\mathrm{CpNiOs}_{3}(\mu-\mathrm{H})_{3}(\mathrm{CO})_{,}(53)$ $\left(\mathrm{Cp}=\mathrm{C}_{3} \mathrm{H}_{s}\right)$ (Figure 4). Thus the corresponding $\mathrm{Ru}, \mathrm{Au}$ and $\mathrm{NiOs}_{3} \mathrm{Au}$ clusters have been shown to have the $\mathrm{Ph}, \mathrm{P} \rightarrow \mathrm{Au}$ fragment occupying the position of the $\mathrm{H}$ atom which they replace $(21,30)$ (Figure 4).

In cases where the location of the $\mathrm{H}$ atom of an hydrido cluster could not be directly found by diffraction methods, the easily determined position of the $\mathrm{Ph}, \mathrm{P}-\mathrm{Au}$ fragment may serve to predict the $\mathrm{H}$ bonding site.

According to the electron counting rules* relating to bonding, the 12 electron $[\mathrm{L} \rightarrow \mathrm{Au}]^{+}$fragment contributes no electron to cluster bonding. As a result, its incorporation into such a system is not expected to alter its structure. An interesting exception is $\mathrm{Os}_{4}(\mathrm{CO})_{22}(\mathrm{AuPPh})_{2}$ which has an $\mathrm{Os}_{8}$ arrangement different to that of the precursor $\mathrm{Os}_{8}(\mathrm{CO})_{22}{ }^{2-}$ (entry 38). The fact that the $\mathrm{L} \rightarrow \mathrm{Au}$ group is found in $\mu_{2}$ - or $\mu_{5}$-positions (or sometimes in intermediate situations) is therefore not surprising. Thus, the two 72 electron clusters ' $\mathrm{NiOs}_{3} \mathrm{Au}$ ' (entry 18) and ' $\mathrm{Co}_{3} \mathrm{RuAu}$ ' (entry 17) have for AuL a $\mu_{2}$ and $\mu$, bonding mode, respectively. This structural difference is best accounted for by the fact that a $\mu_{2}$-AuL fragment acts as an $\mathrm{ML}_{4}$ and a $\mu_{3}$-AuL fragment acts as an $\mathrm{ML}_{3}$ fragment. The former contributes 2 electrons to skeletal bonding whereas the latter allows none, giving an edge-bridged tetrahedral or a trigonal-bipyramidal structure, respectively, following the skeletal electron counting rules (54).

When two or more $\mathrm{L} \rightarrow A \mathrm{u}$ fragments are present in a cluster, the isolobal analogy cannot be applied for predicting the structures since $A u-A u$ bonding interactions between adjacent groups become significant. This is illustrated in the structures depicted in entries 23-33 (Table II) and 39-43 (Table III).

The structural difference between the related $\mathrm{M}, \mathrm{C}(\mathrm{CO})_{n}$ $(\mathrm{AuPPh})_{2}(\mathrm{M}=\mathrm{Fe}, \mathrm{Ru})$ cluster molecules is also noteworthy (entries 34, 35). In view of the growing number of systems involving a triangular $\mathrm{M}\left(\mathrm{AuPR}_{3}\right)_{2}$ unit, it is interesting to compare their structural parameters, as done in Table V. Clearly, most

*A detailed account of these is beyond the scope of this article. Interested readers are referred to K. Wade, Adv. Inorg. Chem, Radiochem., 1976, 18, 67 and D.M.P. Mingos, 'Comprehens. Organometall. Chem., Vol. III', Edited by FJ.A. Stone and J. Wilkinson, Pergamon, Oxford, 1982, p. 1 investigations require structure determinations by $\mathrm{X}$-ray diffraction (55). Interesting information concerning the bonding situation of the gold atom can also be gained from ${ }^{12} \mathrm{Au}$ Mössbauer spectroscopy $(12,56)$.

The principle that seems to govern the build-up of the $\mathrm{L} \rightarrow \mathrm{Au}$ containing clusters is that the first $\mathrm{L} \rightarrow$ Au unit occupies the position of $\mathrm{H}$ in the corresponding hydride, taking into account the steric factors. The successive gold atoms add to the least hindered triangular faces next to existing gold atoms. This leads to a compact arrangement consisting of face-sharing tetrahedra with as many adjacent gold atoms as possible (28). Exceptions have been noted (44) to this general trend.

\section{Cluster - Crystallite Analogies}

It has become very popular to attempt to establish links between the structural and chemical characteristics of molecular clusters and of small crystallites $(5,57)$ and such links and the limitations to these have recently been discussed in respect of homo-nuclear gold cluster molecules in this Bulletin (58). The structures of higher nuclearity gold clusters have even been related to that of the metallic state. With the nuclearity range achieved so far for mixed-metal gold clusters, the scope for similar comparisons is limited. However, as discussed in the preceding section, there is a clear tendency towards structures consisting of face-sharing tetrahedra. Moreover, the

\section{Table V}

Structural Parameters for $M(A u L)$, Complexes

\begin{tabular}{c|c|c|c|c|c}
\hline $\mathrm{M}$ & $\alpha\left({ }^{\circ}\right)$ & $\beta\left({ }^{\circ}\right)$ & $\beta-\alpha\left({ }^{\circ}\right)$ & $\mathrm{Au}-\mathrm{Au}(\mathrm{A})$ & Ref. \\
\hline $\mathrm{Os}$ & 66.9 & 75.8 & 8.9 & $2.929(1)$ & 35 \\
$\mathrm{Pt}$ & 63.5 & 85.2 & 21.7 & $2.737(3)$ & 36
\end{tabular}

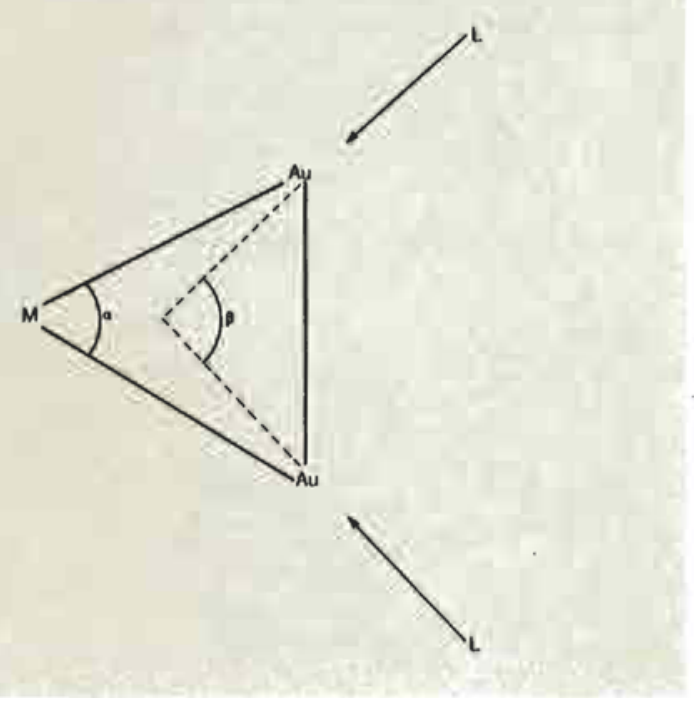




\section{Table Vi}

Comparison Between the Au-M Distances Found in

Molecular Mixed-Metal Clusters and the Sum of the Corresponding Metallic Radil

\begin{tabular}{l|c|c}
\hline $\begin{array}{l}\text { Metallic } \\
\text { couples }\end{array}$ & $\begin{array}{c}\text { Range of determined } \\
\text { values }(\AA)\end{array}$ & $\begin{array}{c}\text { Sum of the metallic } \\
\text { radii }(\AA)\end{array}$ \\
\hline Au-Au & $2.590-3.176$ & 2.878 \\
Au-V & $2.709-2.756$ (a) & 2.77 \\
Au-Cr (b) & $2.635-2.770$ & 2.715 \\
Au-W(b) & $2.698-2.752$ & 2.833 \\
Au-Mn(b) & $2.52-2.57$ & 2.707 \\
Au-Fe & $2.524-3.036$ & 2.699 \\
Au-Ru & $2.633-3.054$ & 2.775 \\
Au-Os & $2.698-2.752$ & 2.789 \\
Au-Co & $2.46-2.868$ & 2.691 \\
Au-Ir & $2.593-2.675$ (a) & 2.794 \\
Au-Pt & $2.600-3.026$ & 2.824
\end{tabular}

(a) Values for only one cluster.

(b) Values given for sake of completeness butconcerning complexes outside the scope of Table I-IV. Au-Cr: Ref. 12a, 13b;

Au-W: Ref. 12b, 13a, 13c; Au-Mn: Ref. $12 c$.

structural data for binary systems such as $\mathrm{Au}-\mathrm{Ru}$ and $\mathrm{Au}-\mathrm{O}$ are difficult to compare with those of binary clusters of these pairs of elements which form a large number of molecular associations despite their immiscibility in the bulk state. However, Table VI gives the actual range of observed $A u-M$ distances determined in the molecular clusters discussed in the previous section and these values are compared with the sum of the metallic radii $R$ for ligancy $12(59)$.

Fig. 5 Interconversion of trigonal bipyramidal and square pyramidal forms of $\left.\mathrm{Ru}_{3}\left(\mu_{1}-\mathrm{S}\right)\right)(\mathrm{CO})_{3}\left(\mathrm{AuPPh}_{3}\right)$, leading to exchange between gold sites: a restricted Berry pseudo-rotation. After (39)
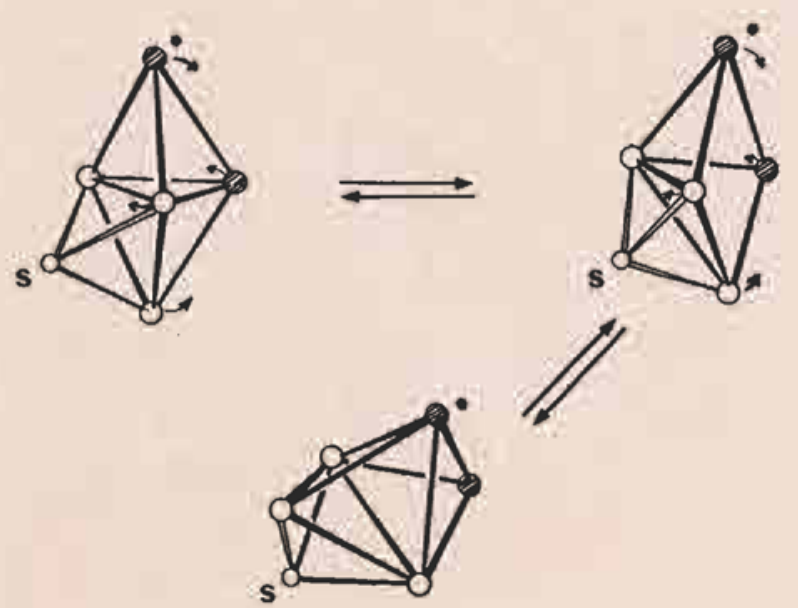

It is usually found that the latter value falls within the Au-M distance range determined by $\mathrm{X}$-ray diffraction.

It has been seen that the cluster structures are dependent on the total electron count but are also sensitive to subtle electronic and steric effects, indicating that they are not inflexible. This is well illustrated by the structural difference between stoichiometrically related clusters $(41,42)$ and also by their stereochemical non-rigidity in solution.

These aspects must be kept in mind when studying the structure, composition and catalytic properties of small alloy particles. Thus, these can be expected to change easily when such particles are applied to substances or their environment changed in other ways.

Interestingly, it will be seen that bimetallic Au-M clusters can have specific reactivities unknown for the homonuclear species, suggesting a parallel with the synergic interactions found for bimetallic particles (see below).

\section{Dynamic Solution Behaviour}

The core flexibility of poly-gold clusters in solution has been investigated by NMR (nuclear magnetic resonance) techniques. This property may be relevant to the construction of metal atom aggregates with unusual geometries and solution dynamics.

Studies dealing with dynamic systems have established that a dissociative mechanism based on gold-phosphorus bond breaking does not operate $(43,48)$. In contrast, facile intramolecular rearrangements of metal atoms occur, which is not surprising in view of the relative weakness of the tangential Au-Au interactions in polygold clusters (58). A Berry pseudo-rotation exchange process accounted for the dynamic behaviour of $\mathrm{Ru}_{3} \mathrm{~S}(\mathrm{CO})_{2} \mathrm{~L}(\mathrm{AuPPh})_{3}$ (entry 28) (Figure 5). Isomers were detected in solutions of $\mathrm{Ru}, \mathrm{WC}(\mathrm{CO})_{12}\left(\mathrm{AuPEt}_{3}\right)_{2}$, the structures of which differ by the locations of the Et, $\mathrm{P} \rightarrow \mathrm{Au}$ fragments: $\mu_{2}$ bridging opposite edges of an octahedron (like the structure of entry 36) or presenting an AuAu unit interacting with one face of the octahedron (entry 37)(43).

These important skeletal rearrangements are low-energy processes. The solid-state structures of these complexes do not fully describe the structures of species present in solution, which may also vary with the solvent. This point is of obvious importance when studying the chemistry or catalytic properties of such clusters.

\section{Chemical Reactivity}

The mixed-metal clusters described above can be expected to display interesting chemical properties associated not only with their lability and ability to undergo facile core rearrangements but also with other factors. Their reactivity, for example, is enhanced by the weakness of their peripheral Au-Au bonds and also by their mixed-metal nature which results in inherently polar Au-M bonds. Furthermore, the gold atoms in these complexes have low-lying, empty orbitals available for an entering nucleophile. Finally, it is possible to envisage that under more forcing conditions, the goldphosphorus bond of a $\mathrm{Ph}_{3} \mathrm{P} \rightarrow \mathrm{Au}$ unit could be broken, resulting 
in new complexes.

Selected examples illustrating the reactivity of these molecular clusters include:

1. The reaction of $\mathrm{NEt}_{3}$, with $\mathrm{Os}_{4} \mathrm{H}_{3}(\mathrm{CO})_{12} \mathrm{AuPPh}_{3}$, inducing a disproportionation of the cluster to $\mathrm{Os}_{4} \mathrm{H}_{4}(\mathrm{CO})_{12}$ and $\mathrm{Os}_{4} \mathrm{H}_{2}(\mathrm{CO})_{12}\left(\mathrm{AuPPh}_{3}\right)_{2}$. This was rationalized in terms of nucleophilic attack by $\mathrm{NEt}_{3}$ at the $\mathrm{AuPPh}$, centre, followed by heterolytic cleavage of the $\mathrm{Au}-\mathrm{O}$ sond and further reaction of the liberated gold cation (40).

2. The reaction of $\mathrm{PPh}_{3}$ with $\mathrm{Co}_{3} \mathrm{Ru}(\mathrm{CO})_{12} \mathrm{AuPPh}_{3}$ producing $\left[\mathrm{Au}\left(\mathrm{PPh}_{3}\right)_{2}\right]\left[\mathrm{Co}_{3} \mathrm{Ru}(\mathrm{CO})_{12}\right]$, again as a result of heterolytic $\mathrm{Au}-\mathrm{Co}$ bond cleavage (60). By contrast $\mathrm{PPh}$, does not cleave the $\mathrm{Au}-\mathrm{V}$ bonds of $\mathrm{V}(\mathrm{CO}),(\mathrm{AuPPh})_{3}$, probably because of the additional $\mathrm{Au}-\mathrm{Au}$ interactions.

3. The structural rearrangement and gold migration observed resulting from the air oxidation of $\mathrm{Fe}_{4} \mathrm{C}(\mathrm{H})(\mathrm{CO})_{12} \mathrm{AuPEt}_{3}$ and $\mathrm{Fe}, \mathrm{C}(\mathrm{CO})_{14}\left(\mathrm{AuPEt}_{3}\right)_{2}$ affording the $\mathrm{Fe}, \mathrm{C}(\mathrm{CO})_{12}\left(\mathrm{AuPEt}_{3}\right)_{2}$ cluster $(26,41)$. It is noteworthy that the $\mathrm{Et}_{3} \mathrm{P} \rightarrow \mathrm{Au}$ migration occurs not only in solution but also in the solid state (41). It is interesting to compare these structures with the iron carbide clusters studied in the context of the $\mathrm{CO}$ reduction (6) and to evaluate the role of the $\mathrm{L} \rightarrow$ Au fragment.

4. The gold-promoted ready formation of gold-iron carbido cluster complexes under relatively mild conditions, starting

Fig. 6 Air oxidation of (a) and (b) results in (c):

(a) $\mathrm{Fe}_{3} \mathrm{C}(\mathrm{CO})$ (AuPEt)

(b) $\mathrm{Fe} \mathrm{C}(\mu-\mathrm{H})(\mathrm{CO}), \mathrm{AuPEt}_{\text {, and }}$

(c) $\mathrm{Fe}, \mathrm{C}(\mathrm{CO})_{12}\left(\mathrm{AuPEt}_{3}\right)_{2}$. After $(26,41)$

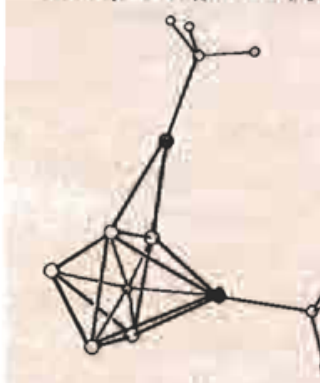

(a)

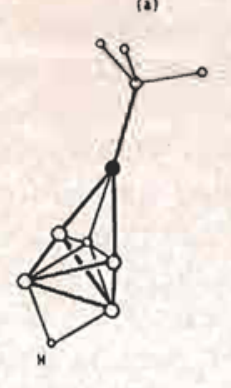

(b) from non-carbido iron clusters (26):

$\left[\mathrm{Fe}_{i}(\mathrm{CO})_{13}\right]^{{ }^{2} \mathrm{R} P} \rightarrow \mathrm{Au}^{*}$ anion $\underset{\rightarrow}{\rightarrow} \mathrm{Fe}_{3,} \mathrm{C}(\mathrm{H})(\mathrm{CO})_{12} \mathrm{AuPR}_{3}$ (see Figure 6)

5. The gold induced nucleophilic attack of an azide ion on a coordinated carbonyl ligand and resulting isocyanate formation (61):

$$
\begin{aligned}
& \mathrm{Os}_{3}(\mathrm{CO})_{12}+\mathrm{NaN}_{3}+\mathrm{Et}_{3} \mathrm{P} \rightarrow \mathrm{AuCl} \longrightarrow \\
& \mathrm{Os}_{3}(\mathrm{CO})_{11}(\mathrm{NCO})\left(\mathrm{AuPEt}_{3}\right) \\
&+\mathrm{Os}_{3}(\mathrm{CO})_{30}(\mathrm{NCO})\left(\mathrm{AuPEt}_{3}\right)
\end{aligned}
$$

It is significant that separate experiments have shown that this isocyanate formation occurs only in the presence of the gold electrophile.

6. The cluster nuclearity increase observed in the transformation of $\mathrm{Os}_{3} \mathrm{H}(\mathrm{CO})_{10} \mathrm{AuPR}_{3}$ into $\left[\mathrm{Os}_{6} \mathrm{AuH}_{2}(\mathrm{CO})_{20}\right]^{2}$, resulting from the $\mathrm{P} \rightarrow \mathrm{Au}$ bond fission (14).

\section{Homogeneous Catalysis}

Only a few heterobimetallic gold-containing molecular species have been investigated as homogeneous catalysts. This situation may change in the near future because of increasing knowledge of the synthesis and structure of mixed metal gold clusters (see above). Some of them could be interesting catalysts or catalyst precursors.

Reported applications of gold-containing mixed metal molecular clusters in homogeneous catalysis include:

- synthesis gas conversion to methanol using $\left\{\mathrm{Ru}_{6} \mathrm{C}(\mathrm{CO})_{\mathrm{ral}}[\mathrm{Au}(\mathrm{NCR})]_{2}\right\}(62)$

- CO conversion to e.g., methanol, ethylene glycol, glycerol and 1,2-propylene glycol, using $\left[\mathrm{Au}_{2} \mathrm{Rh}_{12}(\mathrm{CO})_{30}\right](63)$

One can assume that the polarity of the Au-M bonds in such clusters is a significant factor in determining their reactivity and catalytic actions. It must also be expected that the 'cluster-catalyzed' reactions which they promote will display important solvent effects. The unsaturation of the precursor molecule should also be a determining factor, as illustrated in the next section on supported catalysts.

Fig. 7 In $\mathrm{Ru}_{6} \mathrm{C}(\mathrm{CO})_{16}\left(\mathrm{AuPPh}_{2} \mathrm{Me}\right)_{2}$, two opposite edges of the $\mathrm{Ru}_{6}$ octahedron are bridged by the $\mathrm{L} \rightarrow$ Au fragment (43)

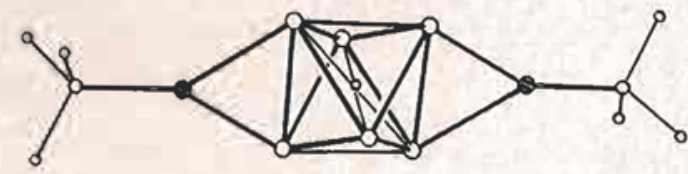




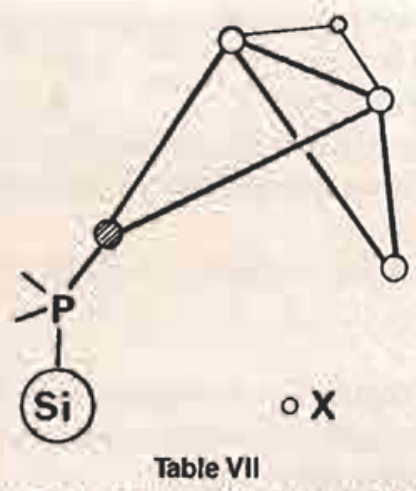

Recent Catalytic Applications of Au-Containing Polymetallic Systems

\begin{tabular}{|c|c|c|}
\hline $\begin{array}{l}\text { Bimetallic } \\
\text { systems }\end{array}$ & Catalysis mode* & Catalyzed reactions \\
\hline \multirow[t]{2}{*}{$\begin{array}{l}\text { Au-Re } \\
\text { Au-Ru }\end{array}$} & c & dehydrocyclization \\
\hline & $\begin{array}{l}c \\
c \\
a \\
c \\
c\end{array}$ & $\begin{array}{c}\text { cyclopropane hydrogenation } \\
\text { hydrogenolysis } \\
\mathrm{CO}+\mathrm{H}_{2} \\
\mathrm{CO}+\mathrm{H}_{2} \\
\text { NOreduction }\end{array}$ \\
\hline $\mathrm{Au}-\mathrm{Os}$ & b & $\begin{array}{l}\text { alkene hydrogenation and isomerization } \\
\text { NO hydrogenation }\end{array}$ \\
\hline Au-Rh & $\begin{array}{l}a \\
c \\
c\end{array}$ & $\begin{array}{l}\mathrm{CO}+\mathrm{H}_{2} \\
\text { alkene hydrogenation } \\
\text { NO hydrogenation }\end{array}$ \\
\hline Au-Pd & $\begin{array}{l}c \\
c \\
c \\
c \\
c \\
c \\
c \\
c\end{array}$ & $\begin{array}{c}\text { alkene hydrogenation and isomerization } \\
\text { NO reduction } \\
\text { oxidative dehydrogenation } \\
\text { alkene oxidation } \\
\text { allyl oxidation } \\
\text { CO oxidation } \\
\mathrm{NH}_{3} \text { oxidation } \\
\mathrm{HCl} \text { addition on }-\mathrm{C} \equiv \mathrm{C}-\end{array}$ \\
\hline Au-Pt & $\begin{array}{l}c \\
c \\
c \\
c \\
c \\
c \\
c \\
c\end{array}$ & $\begin{array}{c}\text { H/D exchange } \\
\text { alkene hydrogenation } \\
\text { NO hydrogenation } \\
\text { Ar- } \mathrm{NO}_{2} \text { hydrogenation } \\
\text { oxygen transfer } \\
\text { hydrocarbon dehydrogenation } \\
\text { skeletal rearrangements and hydrocarbon cracking } \\
\mathrm{HCl} \text { addition on }-\mathrm{C} \equiv \mathrm{C}-\end{array}$ \\
\hline Au-ir & $c$ & skeletal rearrangement and dehydrocyclization \\
\hline$A u-A g$ & c & $\begin{array}{l}\text { alkene oxidation } \\
\text { methanol oxidation }\end{array}$ \\
\hline Trimetallic & Catalysis mode & Catalyzed reactions \\
\hline Au-Co-Ru & c & $\begin{array}{l}\text { alkene hydrogenation } \\
\text { nitrile hydrogenation }\end{array}$ \\
\hline $\mathrm{Au}-\mathrm{Pd}-\mathrm{Cu}$ & c & allyl oxidation \\
\hline$A u-P d-A g$ & c & allyl oxidation \\
\hline
\end{tabular}

"(a) homogeneous catalysis; (b) supported catalysis (see text); (c) heterogeneous catalysis.
Fig. 8 Structures of $\mathrm{Os}_{3}(\mu-\mathrm{X})(\mathrm{CO})_{10}\left(\mathrm{AuPPh}_{2}\right.$-(Si)

$X=\mathrm{X}$, butterfly angle $: 109.8^{\circ}(23)$

$\mathrm{X}=\mathrm{Cl}$, butterfly angle $: 121.4^{\circ}(22)$

\section{Supported Organometallic Catalysis}

The aim of supported organometallic catalysis is to combine the selectivity of homogeneous catalysts with the increased stability and ease of recuperation of heterogeneous systems.

It is expected therefore that the catalytic properties of an increasing number of molecular mixed-metal clusters anchored on organic or inorganic supports will be studied in the future. In this approach to the development of catalytic systems, metals which do not form bulk binary alloys can be associated at the molecular level. Novel catalyst preparations and new catalytic reactions can therefore be expected to result from their study.

The role of the support and the method of preparation of the catalyst is particularly evident from studies dealing with the same precursor molecules. Moreover, by applying different precursors to the same substrate under similar conditions, the variations in catalytic activity arising from differences in their structures can be studied. Thus the $\mathrm{HAuOs}_{3}(\mathrm{CO})_{14} \mathrm{PPh}_{3}$ and $\mathrm{ClAuOs},(\mathrm{CO})_{10} \mathrm{PPh}$, clusters were anchored intact on to phosphine-functionalized silica $(64,65)$ or polymer (styrene-divinylbenzene) (65). With both supports it was found that the 'HAuOs,' cluster was inactive for alkene hydrogenation and isomerization. In contrast, the 'ClAuOs,' cluster was active for alkene hydrogenation, although it was found to have lower stability on silica-based supports than on the preferred polymers $(64,65)$. This different behaviour was initially incorrectly attributed to differing (tetrahedral and butterfly) structures in these clusters. It has been established, however, that both clusters are of the butterfly type with 58 and 60 electrons respectively, for $\mathrm{X}=\mathrm{H}$ and $\mathrm{X}=\mathrm{Cl}$ (Figure 8). 
Phosphine substituted molecular mixed-metal clusters are especially suitable for production of heterogeneous catalysts since they easily undergo phosphine-phosphine exchange under mild conditions and can therefore be anchored on phosphinefunctionalized supports.

The thermal instability of heterogenized clusters is, however, a limitation to their use in catalysis.

\section{Heterogeneous Catalysis by Bimetallic Particles and Alloys}

Schwank has reviewed elsewhere in this issue of Gold Bulletin the structures, properties and applications of bimetallic catalysts based on gold together with palladium, platinum and ruthenium respectively. The phase diagrams for the corresponding three binary alloy systems exhibit respectively complete miscibility, partial miscibility and virtually total immiscibility. Especially with systems of the latter types, the available data indicate that bimetallic catalysts can be non-uniform and show massive variations in morphology and particle composition depending upon their methods of production, theirsupports and their treatment. In many instances gold seems to act as an inert diluent which reduces activity by disrupting the cluster or ensemble effects of the active surface atoms. Such disruption appears also to give rise to catalyst selectivity in some catalysts. In all catalysts it is the surface composition and surface structure which determines activity and selectivity, and the segregation, support and other factors that determine these properties are all-important, and have been well illustrated by Schwank.

In comparison, relatively little is as yet known about the composition, structures and properties of small bimetallic particles formed by the application of bimetallic cluster compounds to different supporting materials. As has been illustrated above, however, there is a rapidly developing knowledge of the structures of gold-containing molecular clusters so that the stage is being set for further developments.

In conclusion, and as a supplement to the review by Schwank, we present in Table VII a summary of the gold-containing bimetallic systems which have been moststudied, together with the catalytic reactions which they promote. It will be apparent from this that most studies that have been reported upon concern only a limited number of couples. This suggests that much remains to be done in this whole area of bi- and multi-metallic catalysis. It serves to emphasise the wide scope which exists for exploring the use of molecular bimetallic clusters in the production of new catalytic materials.

\section{Other Applications of Gold-based Bimetallic Systems}

Gold has a number of specific applications due to its unique physicochemical properties. It is often associated with another metal to improve the properties of the single component system. These goals are fulfilled by the use of either 'controlled impurities' or specific supports. Examples of these are materials with specific, novel, and/or improved conducting (66-67), optical (78-82), magnetic (83-88), mechanical (89-94), photographic (95-101), protecting properties (102-104), and of dental (105-108), medical $(104,109)$, or ornamental applications $(93,110-113)$.

\section{References}

1 'Transition Metal Clusters', edited by B.FG. Johnson, John Wilcy and Sons Ltd., 1980

2 W.L. Gladfelter and G.L. Geoffroy, Adt. Organometal. Chem., 1980, 18, $207-273$

3 H. Vahrenkamp, Adv. Organometal. Chem., 1983, 22, 169-208

4 E. Band and E.L. Muetterties, Chem. Rev., 1978 78, (6), 639-658

5 E.L. Muetterties, T.N. Rhodin, E. Band, C.F. Brucker and W.R. Pretzer, Chem. Rev., 1979,79,91

6 J.S. Bradley, Adv. Organometal. Chem., 1983, 22, 1.58

7 J.H. Sinfel, J. Catal, , 1973, 29, 308

8 J.H. Sinfelt, L.Y. Lam, J.A. Cusumano and A.E. Barnetr, J. Catal., 1976, 42, 227

9 D.G. Evans and D.M.P. Mingos, J. Organometal. Chem., 1982, 232, 171

10 J.W. Lauher and K. Wald, J. Am. Chem. Soc., 1981, 103, 7648

11 A.G. Orpen, J. Organometal. Chem., 1978, 159, C1-C4

12 (a) P. Braunstein. U. Schubert and M. Burgard, Inorg. Chem. in Press. (b)J.B. Wilford and M.H. Powell, J. Chem. Soc (A), 1969, 8-15. (c) K.A.I.F.M. Mannan, Acta Crystallogr., 1967, 23, 649-653

13 (a) M.R. Awang, G.A. Carriedo, J.A.K. Howard, K.A. Mead, I. Moore, C.M. Nunn and F.G.A. Stone, J. Chem. Soc. Chem. Commun. 1983, 964. (b) M. Green, A.G. Orpen, I.D. Salter and F.G.A. Stone, J. Chem. Soc. Chem. Commun, 1982, 813-814. (c) G.A. Carriedo D. Hodgson, J.A.K. Howard, K. Marsden, F.G.A. Stone, M.J. Went and P. Woodward, J. Chem. Soc, Chem. Commun., 1982, 1006-1008

14. B.F.G. Johnson, D.A. Kaner, J. Lewis and P. Raithby, J. Chem. Soc. Chem. Commun., 1981, 753-755

15 M.I. Bruce and B.K. Nicholson, J. Organometal. Chem. 1983, 250, 627
16 G. Iavigne, F. Papageorgiou and J.J. Bonnet, Inozg. Chem., 1984, 23, 609-613

17 M.J. Mays, P.R. Raithby, P.L. 'Taylor and K. Henrick, J. Organometal. Chem., $1982,224, C 45$

18 L.W, Bateman, M. Green, J.A.K. Howard, K.A. Mead, R.M. Mills, I.D. Salter, F.G.A. Stone and P. Woodward, J. Chem. Soc. Chem. Commun, 1982, 773

19 L.W. Bateman, M. Green, K.A. Mead, R.M. Mills, I.D. Salter, F.G.A. Stone and P. Woodward, J. Chem. Soc, Dalton Trans, 1983, 2599

20 M. Green. K.A. Mead, R.M. Mills, I.D. Salter, F.G.A. Stone and P. Woodward, f. Chem. Soc, Chem. Commun., 1982, 51

21 P. Braunstein, G. Predieri, A. Tiripicchio and E. Sappa, Inorg. Cbim. Acta, 1982 63,113

22 C.W. Bradford, W. van Bronswijk, R.J.H. Clark and R.S. Nyholm, J. Chem. Soc., 1970,2889

23 B.F.G. Johnson, D. A. Kaner, J. Lewis and P.R. Raithby, J. Organometal. Chem., $1981,215, \mathrm{C} 33$

24 C.E. Briant, R.M.W. Wardle and D.M.P. Mingos,J. Organometal. Ghem., 1984, 267, C49-C51

25 K. Fischer, M. Muller and H. Vahrenkamp, Angew. Chem., 1984, 96, 138

26 B.F.G. Johnson, D.A. Kaner, J. Lewis, P.R, Raithby and M.J. Rosales, J. Organometal. Chem. 1982, 231, C59

27. B.F.G. Johnson, D.A. Kaner, J. Lewis, P.R. Raithby and M.J. Taylor, J. Chem Soc. Chem. Commun., 1982, 314

28 M.I. Bruce and B.K. Nicholson, Organometall., 1984, 3, 101

29 P. Braunstein, J. Rose, Y. Dusausoy and J.P. Mangeot, C.R. Acad. Sci. Ser, 11 $1982,294,967$ 
30 P. Braunstein, J. Rose, A.M. Manotti-Lanfredi, A. Tiripicchio and E. Sappa J. Chem. Soc. Dallon Tians, 1984, 1843

31 B. F.G. Johnson, J. Lewis, J.N. Nicholls, J. Puga and K.H. Withmire, J. Chem. Soc. Dalton Tians., 1983, 787

32 B.F.G. Johnson, J. Lewis, W.J.H. Nelson, J. Puga, P.R. Raithby, D. Braga, M. McPartlin and W. Clegg, J. Organometal, Chem., 1983, 243, C13

33 B.F.G. Johnson, J. Lewis, W.J.H. Nelson, M.D. Vargas, D. Braga and M. McPartlin J. Organametal. Chem., 1983, 246, C69

34 J.W. Lauher and $\mathrm{K}$. Wald, unpublished results cired in (35)

35 B.F.G. Johnson, J. Lewis, P.R. Raithby and A. Sanders, J. Organometal. Chem., $1984,260, \mathrm{C} 29$

36 P. Braunstein, H. Lehner, D. Matt and A. Tiripicchio, Angew. Chem., 1984, 96 304

37 C.E. Briant, D.I. Gilmour and D.M.P. Mingos, J. Organometal. Chem., 1984, 267, CS2-CSS

38 E. Roland, K. Fischer and H. Vahrenkamp, Angew. Chem. Int. Ed. Eng,, 1983, 22,326

39 L.J. Farrugia, M.J. Freeman, M. Green, A.G. Orpen, F.G.A. Stone and I.D. Salter, J. Organometal, Chem., 1983,249, 273

40 B.F.G. Johnson, D.A. Kaner, J. Lewis, P.R. Raithby and M.J. Taylor, Polybedron, $1982,1,105$

41 B.F.G. Johnson, D.A. Kaner, J. Lewis and M.J. Rosales, J. Organometal. Chem., $1982,238, C 73$

42 B.F.G. Johnson, J. Lewis, J.N. Nicholls, W.J.H. Nelson, J. Puga and M.D. Vargas, J. Chem. Soc. Dalton Trans., 1983, 2447

43 S.R. Bunkhall, H.D. Holden, B.F.G. Johnson, J. Lewis, G.N. Pain, P.R. Raithby and M.J. Taylor, J. Chem. Soc. Chem. Commun., 1984, 25

44 B.F.G. Johnson, J. Lewis, W.J.H. Nelson, P.R. Raithby and M.D. Vargas, J. Chem. Soc. Chem. Commun., 1983,608

45 J.E. Ellis, $J$. Am. Chem. Soc., 1981, 103,6106

46 A.L. Casalnuovo, L.H. Pignolet, J.W.A. van der Vclden, J.J. Bour and J.J. Steggerda, J. Amn. Chem. Soc, 1983, 105, 5957

47 (a) M.I. Bruce and B.K. Nicholson, J. Organometal. Chem., 1983, 252, 243. (b) ibid, J. Chem. Commun., 1982, $114 \mathrm{I}$

48 J.A.K. Howard, I.D. Salter and F.G.A. Stone, Polybedron, 1984, 3, 567

49 C.E. Briant, K.P. Hall and D.M.P. Mingos, J. Chem. Soc. Chem. Commun. 1983, 843

50 J.W.A. van der Velden, J.J. Bour, B.F. Otterloo, W.P. Bosman and J.H. Noordik, J. Chem. Soc. Chem. Commun., 1981, 583

51 E.C. Coffey, J. Lewis and R.S. Nyholm, J. Chem. Soc. (A), 1964, 1741

52 M. Carti, G. Gervasio and S. A. Masonij. Chem. Soc. Dalton Trans, 1977, 2260

53 M.R. Churchill and C. Bueno, Inorg. Chem., 1983, 22, 1510

54 K. Wade, Adv. Inorg. Chem. Radiochem, 1976, 18, 1; J.W. Lauher, J. Am. Chem. Soc., 1978, 100, (7), 5305-5315; D.G. Evans and D.M.P. Mingos, Organometall. 1983, 2, 435-447

s5 P.G. Jones, Gold Bull., 1981, 14, 102-118 and 159-166; Gold Bull., 1983, 16, 114-124

56 R.V. Parish, Gold Bull., 1982, 15, (2), 51-63

57 E.L. Muetterties, Science, 1977, 196, (4292), 839-848

58 D.M.P. Mingos, Gold Bull., 1984, 17, (1), 5-12

59 L. Pauling, in 'The Nature of the Chemical Bond', Third Edition, Cornell University Press, (New York), 1962, p 403

60 P. Braunstein, J. Rose, A.M. Manorti-Lanfredi and A. Tiripicchio, submitted to ]. Chem. Soc. Dalton Trans.

61 K. Burgess, B.F.G. Johnson and J. Lewis, J. Chem. Soc. Dalton Trans, 1983, 1179-1183

62 Exxon Research and Engincering Co., Eur: Pat. 37700

63 Union Carbide Corp., U.S. Pat. 3, 878, 292

64 M. Wolf, H. Knözinger and B. Tesche, J. Mol. Catal., 1984, 25, 273-283
65 R Pierantozzi, KJ. McQuade, BC Gates M Wolf, H Knözinger and W. Ruhmann, J. Am. Chem. Soc., 1979, 101, 5436; R. Pierantozzi, K.J. MicQuade and B.C. Gates, Stud. Surf. Sci. Catal., 1981, 7, (Pt. B. New Horiz. Catal.), $941-952$

66 J.F. March and F. Thurley, Rev. Sci. Instrum., 1979, 50, (5), 616-618

67 Anon., Gold Bull., 1979, 12, (2), 74

68 M.R. Pinnel, Gold Bull., 1979, 12, (2), 62-71

69 H. Becker and R. Schnabl, Gold Bull,, 1982, 15, (3), 78-80

70 J.W. Mayer, Gold Butl., 1984, 17, (3), 18-26

71 T, Goto, Trans. Japan Inst. Met. 1983, 24, 595-600

72 Matsushita Electrical Industrial Co. Led., Japanese Prelim. Pat. 83-104184

73 O. Rapp, Phys. Lett., 1977, 64A, (1), 75-77

74 P.H. Holloway, Gold Bull., 1979, 12, (3), 99-106

75 Yu Mei, E.H. Tyler and H.L. Luo, Phys. Rev. B, 1982, 26, (8), 4299-4304

76 M. Antler, Gold Bull., 1983, 16, (1), 2-7

77 S.C. Abrahams, J.L. Bernstein, R. Liminga and E.T. Eisenmann, J. Chem. Phys., $1980,73,4585$

78 C. Jung and M.P. Stoll, Y. Phys. Chem. Solids, 1980, 41, (2), 161-171

79 M. Tamatani, Gold Bull, , 1980, 13, (3), 98-104

80 P.W. Filberg and A. Bittar, J. Phys, F: Met. Phys, 1982, 12, (7), 1487-1495

81 P. Picozzi, S. Santucci, M. Didciaiuti and L. Padletti, Opt. Acta, 1982, 29, (4), $511-517$

82 E.F.I. Roberts and K.M. Clarke, Gold Bull., 1979, 12, (1), 9-19

83 'T. Kaneko, S. Abe, K. Kamigaki and M. Ohashi,J. Magn. Miagn. Mater, 1983, 31-34, (1), 253-254

84 Yu. G. Karpov, F.A. Sidorenko, V.V. Slobodenyuk, P.N. Syutkin and A.A. Kuranov, Fiz Met. Metalloved, 1979, 48, (3), 498.504

85 C.M. Hurd, S.P. McAusterand I. Shiozaki, Conf. Ser.--Int. Phys., 1981, 55 (Phys. Transition Met.), 475-478

86 R.T. McGuire, J.A. Aboaf and E. Klokholm, J. Appl. Phys., 1981, 52, (3, P. 2), 2205-2207

87 Ishifuku Kinzoku Kogyo K.K., Japanese Prelim. Publ., 82-5883

88 C.S. Severin and C.W. Chen, J. Appl. Phys, 1982, 53, (11), 7744-7746

89 D. Ott and Ch. J. Raub, Metall., 1980, (7), 629-633

90 K. Okazaki, Shika Rikogaku Zasshi, 1979, 20, (52), 233-239

91 Licentia Patcnt-Verwaltung GmbH, German Offen., 3202160

92 A. Bischoff and F. Aldinger, Metall., 1982, 36, (7), 752-756

93 Ch. J. Raub and D. Ott, Gold Bull., 1983, 16, (2), 46-51

94 A.E. Heywood and R.A. Benedek, Plat. Met. Rev, 1982, 26, (3), 98-104

95 D.J. Cash, Photogr. Sci. Eng., 1983, 27, 156-160

96 W.F. Berg, Gold Bulll, 1979, 12, (3), 97.98

97 Anon., Gold Bull., 1982, 15, (1), 20

98 D. A. Pitt, M.L. Rachu and R.V. Sahyun, Photogr. Sci. Eng., 1981, 25, (2), 57-62 99 G. Burge, J. Electrochem. Soc, 1982, 129, (2), 591-595

100 Ciba-Geigy A.G., U.K. Pat. Appl., 2078990 A

101 J.W. Mitchell, Photogr. Sci. Eng. 1979, 23, (1), 1-19

102 A.J. Forty, Gold Bull., 1981, 14, (1), 25-35

103 H.T. Slover, J. High Resol. Chromatogr. Commutn., 1983, 6, 392-393

104 D.C. Wright, R.F. Gaillant and L. Spanberg, J. Biomed. Mat. Res, , 1982, 16, $509-517$

105 J.J. Labarge, D. Treheux and P. Guiraldenq, Gold Bulll, 1979, 12, (2), 46-52 106 H. Ohno and Y. Kanzawa, J. Mat. Sci, 1983, 18, 919-929

107 J.A. Donaldson, Gold Bull., 1980, 13, (4), 160.165

108 H. Hero, R. Jorgensen and E. Sorbroden, J. Dent. Res, 1982, 61, 1292-1298 109 C. Reinicke, Zbl. Pharm., 1978, 117, 728-731

110 Shiseido Co. Ltd., Japanese Prelim. Publ. 79-162618

111 I.B. MacCormack and J.E. Bowers, Gold Bull., 1981, 14, (1), 19-23

112 M.R. Pinasco and E. Stagno, Gold Bull., 1979, 12, (2), 53-57

113 G. Bacquias, Gold Bull., 1982, 15, (4), 124-129 